\title{
The Model for End-Stage Liver Disease (MELD) can predict outcomes in ambulatory patients with advanced heart failure who have been referred for cardiac transplantation evaluation
}

\author{
Bożena Szyguła-Jurkiewicz' ${ }^{1}$ Michał Zakliczyński², Mariusz Andrejczuk², Mateusz Mościński ${ }^{3}$, Marian Zembala² \\ ${ }_{1}^{1}{ }^{\text {rd }}$ Department of Cardiology, Medical University of Silesia, School of Medicine with the Division of Dentistry in Zabrze, \\ Silesian Center for Heart Diseases, Zabrze, Poland \\ ${ }^{2}$ Department of Cardiac Surgery and Transplantation, Medical University of Silesia, School of Medicine with \\ the Division of Dentistry in Zabrze, Silesian Center for Heart Diseases, Zabrze, Poland \\ ${ }^{3}$ Cardiology Department, Regional Specialist Hospital No 4, Bytom, Poland
}

Kardiochirurgia i Torakochirurgia Polska 2014; 11 (2): 178-181

\begin{abstract}
Risk stratification in heart failure (HF) patients is an important element for management. There are several risk stratification models that can be used to predict the prognosis of patients with HF, such as Aaronson's scale, CVM-HF (CardioVascular Medicine Heart Failure), the Seattle Heart Failure Model (SHFM) and the Munich score. These models fail to adequately address the impact of multiorgan dysfunction on prognosis.

The classical Model for End-Stage Liver Disease (MELD) score consists of: total bilirubin, INR (international normalized ratio) and creatinine level. There are some modifications of the MELD scale: MELD-XI, which excludes the INR score; the modMELD score, in which INR is replaced with albumin levels; and MELD-Na, which consists of the bilirubin and creatinine levels, INR ratio and the sodium level. Therefore, the MELD score systems are markers of multisystem dysfunction (renal, cardiac, hepatic). It is important that they are composed of routinely collected laboratory measures which are easy to use.
\end{abstract}

Key words: chronic heart failure, prognosis, MELD scale.

\section{Introduction}

Risk stratification in an etiologically and functionally inhomogeneous group of heart failure (HF) patients is an important element for management from both a medical and an economic point of view. Accurate identification of patients who are most likely to benefit from heart transplantation is imperative due to an organ shortage and perioperative complications [1, 2].

\section{Streszczenie}

W etiologicznie i funkcjonalnie niejednorodnej grupie chorych z niewydolnością serca istotnym elementem postępowania jest stratyfikacja ryzyka. Istnieją liczne modele prognostyczne stosowane do oceny ryzyka u chorych z niewydolnością serca, takie jak: skala Aaronsona, skala CVM-HF (CardioVascular Medicine Heart Failure), skala Seattle (The Seattle Heart Failure Model) i skala Monachium. Wymienione skale nie biorą jednak pod uwagę markerów dysfunkcji wielonarządowej mających istotne znaczenie rokownicze w tej grupie chorych. W skład klasycznej skali MELD (Model for End-stage Liver Disease) wchodzi natomiast stężenie bilirubiny, wskaźnik INR oraz stężenie kreatyniny. Istnieje kilka modyfikacji skali MELD: skala MELD XI, z której wyeliminowano wskaźnik INR, skala modMELD, w której wskaźnik INR został zastąpiony przez stężenie albumin, oraz skala MELD-Na, obejmująca stężenie kreatyniny, bilirubiny, sodu i wartość wskaźnika INR. Skale MELD są więc markerami dysfunkcji wielonarządowej (nerkowej, sercowej, wątrobowej). Ich zaletą jest to, że w ich skład wchodzą rutynowo oceniane parametry laboratoryjne.

Słowa kluczowe: przewlekła niewydolność serca, rokowanie, skala MELD.

There are several risk stratification models that can be used to predict the prognosis of patients with HF. The first is Aaronson's scale, which consists of such clinical data as resting heart rate, left ventricular ejection fraction, mean blood pressure, interventricular conduction defects, serum sodium, mean wedge pressure, ischemic etiology of cardiomyopathy and assessment of peak oxygen consumption [3]. The necessity for the assessment of peak oxygen con-

Address for correspondence: Assoc. Prof. Bożena Szyguła-Jurkiewicz, $3^{\text {rd }}$ Department of Cardiology, Medical University of Silesia, School of Medicine with the Division of Dentistry in Zabrze, Silesian Center for Heart Diseases, Zabrze, Poland, Marii Curie-Sklodowskiej 9 , 41-800 Zabrze, Poland, tel. +48 60410 299, e-mail: centrala4@wp.pl 
sumption limits the possibility of using this model widely. In addition, changes in the medical treatment of HF since 1995 (especially the widespread use of $\beta$ blockers) and the predictive value of hemodynamic changes over time are not adequately taken into account in Aronson's stratification model $[1,4]$.

The next prognostic scale is the CVM-HF, which was created by Senni et al. in 2006 and includes: medications ( $\beta$ blockers, ACEI), NYHA class III/IV, left ventricular ejection fraction $<20 \%$, severe valvular heart disease, atrial fibrillation and coexisting diseases (anemia, arterial hypertension, chronic obstructive pulmonary disease, complicated diabetes mellitus, moderate to severe kidney dysfunction, metastatic cancer) [5]. This model was derived and validated in a single center with stable HF patients who were mostly undergoing optimal pharmacological treatment. The limitations of this model are that patients with preserved and impaired systolic function were included in the study group and the study group was relatively small.

The Seattle Heart Failure Model (SHFM) was constructed in 2006 by Levy et al. It was developed in the PRAISE-1 database and validated among patients participating in observational studies, clinical trials and registries (ELITE-2, Val-HeFT, University of Washington cohort, RENAISSANCE and Italian Heart Failure Registry). An SHFM score is calculated based on 24 variables, including clinical characteristics (gender, age, NYHA class, weight, ischemic etiology, systolic blood pressure, left ventricular ejection fraction), laboratory data (serum cholesterol, sodium and uric acid level, lymphocyte percentage, hemoglobin), medications and device therapy (implantable cardioverter-defibrillator, cardiac resynchronization therapy) [6]. This model consists of a large number of parameters, such as commonly obtained baseline clinical data, medications and devices, which do not reflect the multiorgan dysfunction that is the essence of advanced heart failure.

The next risk stratification scale, which was created in 2008, is the Munich score [7]. This model contains five parameters: etiology of HF, systolic blood pressure, left ventricular end diastolic diameter, maximum workload and the change in the fractional shortening of the left ventricle over 12 months. This scale offers an efficient and non-invasive tool for pre-transplant risk stratification. Univariate and multivariate analyses in this model show no statistical significance of elements of Aronson's scale such as heart rate at rest, serum sodium, intraventricular conduction defect or peak oxygen consumption. Its main limitation is that the data came from a single center and this scale predicts a combined end point (death and heart transplantation).

The changes in medical treatment and device therapy of HF over time are not adequately taken into account in the above-mentioned stratification models. In addition, although a number of risk stratification scales have been established to assess risk in heart failure patients who are referred for heart transplantation evaluation, these models fail to adequately address the impact of liver dysfunction.
Abnormal liver function tests that reflect liver dysfunction are important indices of heart failure severity and higher risk of death [8]. The pathophysiology of liver failure in heart failure has been attributed to venous congestion and reduced cardiac output that leads to hepatic congestion and hepatic low perfusion [9]. Low perfusion is less important than congestion because oxygen consumption can be increased when hepatic blood flow is decreased [10, 11]. Moreover, compared to other organs, the liver's dual blood supply (from the portal system and hepatic artery) makes it relatively resistant to hepatocyte necrosis from haemodynamic instability $[9,12]$.

For these reasons chronic cardiac hepatopathy shows no significant deviations from physiologic levels of transaminases. A critical elevation of transaminases is observed only in cases of marked hypotension $[10,13]$. Multiple studies have shown a decrease in serum total protein, albumin, coagulation factors and lipid levels and as a result cachexia and bleeding [13].

Most frequently, we can observe a mild increase in the serum bilirubin level (in 30-70\% of patients) and an increased level of other cholestatic indices such as alkaline phosphatase or $\gamma$-glutamyltranspeptidase (in $20 \%$ of patients) $[9,14,15]$. Several studies performed on heart failure patients have shown that serum bilirubin level correlates with hemodynamic parameters such as right atrial pressure, severity of tricuspid regurgitation, wedge pressure, left ventricular ejection fraction and the cardiac index $[8,10,16]$.

Two non-cardiac biomarkers which reflect the severity of the effect of hepatic dysfunction on metabolism (total bilirubin) and synthesis (INR - international normalized ratio) are elements of the classical Model for End-Stage Liver Disease (MELD) score. The third component of the MELD score system is the creatinine level. Therefore, the MELD score system is a marker of multisystem dysfunction (renal, cardiac, hepatic) and coagulopathy. It is composed of three routinely collected laboratory measures which are easy to use.

The MELD was initially developed to assess mortality in subjects with cirrhosis who had undergone transjugular intrahepatic portosystemic shunt procedures [17, 18]. In addition, it was validated as a predictor of survival in patients with end-stage liver disease. Moreover, the clinical utility of MELD was used to select patients who might profit from liver transplantation and to predict operative morbidity and mortality in cirrhotics undergoing cardiac and noncardiac procedures $[19,20,21]$. Northup et al. and Ailavadi et al. observed dependence between the MELD score and postoperative mortality in the group of non-cardiac cirrhotic patients undergoing non-transplant procedures [22, 23]. MELD is currently applied to determine the prognosis of patients with chronic heart failure who are referred for mechanical circulatory support or heart transplantation $[24,25]$.

Matthews et al. analyzed patients from the INTERMACS (Interagency Registry of Mechanically Assisted Circulatory Support) registry and the UMHS (University of Michigan Health System) mechanical circulatory support database 
[24]. These authors demonstrated that preoperative MELD scores can identify left ventricular assist device candidates who are at high risk for perioperative bleeding and mortality. This analysis showed an increased frequency of postoperative device infections and renal failure in patients who required many perioperative transfusions. The association between the MELD score and renal failure is due to the fact that creatinine is a part of the MELD model. The association between the MELD score and infection may be related to bacterial exposures during prolonged intensive care unit and total hospital stays. In addition, Matthews et al. have demonstrated an increased frequency of right ventricular failure in patients with higher MELD scores. The reason cited for this was that blood transfusions can increase the right ventricular preload and provoke the release of cytokines which then cause respiratory insufficiency and pulmonary hypertension. Many transfusions also increase risk of allosensitization, which is associated with a worse outcome in patients after heart transplantation [26].

Chokshi et al. [25] retrospectively analyzed patients before and after heart transplantation and assessed the serum levels of hepatic function tests and MELD scores. The percentage of patients with a pathologic serum level of hepatic function markers decreased significantly after heart transplantation. Elevated MELD scores also improved after heart transplantation. The authors confirmed that liver dysfunction was associated with higher rates of postoperative complications and an impaired prognosis in patients undergoing orthotopic heart transplantation. They concluded that higher MELD scores can identify patients who are at a higher risk for complications and reduced survival after heart transplantation.

The MELD score may not be a valid prognostic index in patients who are undergoing warfarin therapy because warfarin affects the international normalized ratio (INR). There are some alternative MELD scales without INR.

An alternative MELD scale that omits INR, which can be used for patients undergoing anticoagulant therapy, was created by Heuman et al. [27]. The authors confirmed that a modified MELD score, MELD-XI (MELD excluding INR score), which is calculated based on two parameters, bilirubin and creatinine, was a predictor of pretransplant mortality in cirrhotic patients. Comparable MELD and MELD-IX scores were associated with a comparable prognosis.

Assenza et al. adopted the MELD-IX score to determine disease severity and to predict mortality in patients who were undergoing Fontan surgery [28]. They concluded that patients with a higher MELD-XI score have higher risk of death and cardiac transplantation.

Tsuda et al. excluded the INR variable from the MELD score and created a simplified model which only used total bilirubin and creatinine [29]. The authors assessed the ability of this scale to predict mortality for patients who were undergoing tricuspid valve surgery. This analysis demonstrated that the simplified MELD score was an independent risk factor for hospital mortality and morbidity.
Choshi et al. [25] used a modified MELD score that replaced INR with albumin levels to substitute for the impaired production of coagulation factors of prothrombin complex with albumin. The substitution of INR with albumin was based on the fact that both are indicators of secretory liver function. The modified MELD score correlates with the standard score and is better than the standard score due to the lack of an interaction with oral anticoagulants. Elevated modified MELD scores before heart transplantation were associated with worse morbidity and mortality after the operation.

Kim et al. evaluated the MELD score and its modifications in predicting survival and endpoint (death, heart transplantation, ventricular assist device implantation) in a group of end-stage heart failure patients who were undergoing a cardiac transplantation evaluation [30]. They compared the prognostic value of MELD, MELD-XI and MELD-Na in patients who were either on or off anticoagulant treatment. MELD-Na consisted of the bilirubin and creatinine levels, INR ratio and the sodium level, which is an important marker of mortality. The authors found that MELD was a good predictor of a worse outcome and that the presence of serum sodium in the MELD scale resulted in an improved prognostic strength. This relationship was evident in patients without oral coagulation. For patients being treated with anticoagulation, MELD-XI was a prognostic factor of the necessity of heart transplantation. MELD-XI had a worse prognostic strength in patients being treated with oral anticoagulation compared with patients who were not receiving anticoagulation therapy. The reason for this could be the fact that patients receiving anticoagulation have multiple comorbidities which are risk factors of poorer outcome.

In conclusion, the Aaronson and Seattle scales that were previously used widely demonstrated a high prognostic value in ambulatory patients with stable heart failure. The predictive value of Aaronson's scale is less reliable today than it used to be due to the changes in the guidelines on the management of heart failure. The MELD scale and its modifications are better in terms of a prognostic index in patients with advanced heart failure than previous models because they take into account multiorgan failure, which is the essence of this pathological state. They show an increased risk of death due to heart failure decompensation. A good option is to use the MELD-XI scale combined with other prognostic models for patients who need oral anticoagulation.

\section{References}

1. ESC Guidelines for the diagnosis and treatment of acute and chronic heart failure 2012. The Task Force for the Diagnosis and Treatment of Acute and Chronic Heart Failure 2012 of the ESC. Developed in collaboration with the Heart Failure Association (HFA) of the ESC. Eur Heart J 2012; 33: 1787-1847.

2. Stehlik J, Hosenpud JD, Edwards LB, Hertz MI, Mehra MR; International Society for Heart and Lung Transplantation. ISHLT International Registry for Heart and Lung Transplantation-into the fourth decade, from strength to strength. J Heart Lung Transplant 2013; 32: 941-950.

3. Aaronson KD, Schwartz JS, Chen TM, Wong KL, Goin JE, Mancini DM. Development and prospective validation of a clinical index to predict survival in 
ambulatory patients referred for cardiac transplant evaluation. Circulation 1997; 95: 2660-2667.

4. Koelling TM, Joseph S, Aaronson KD. Heart failure survival score continues to predict clinical outcomes in patients with heart failure receiving betablokers. J Heart Lung Transplant 2004; 23: 1414-1422.

5. Senni M, Santilli G, Parella P, De Maria R, Alari G. Berzuini C, Scuri M, Filippi A, Migliori M, Minetti B, Ferrazzi P, Gavazzi A. A novel prognostic index to determine the impact of cardiac conditions and co-morbidities on one-year outcome in patients with heart failure. Am J Cardiol 2006; 98: 1076-1082.

6. Levy WC, Mozaffarian D, Linker DT, Sutradhar SC, Anker SD, Cropp AB, Anand J, Maggioni A, Burton P, Sullivan MD, Pitt B, Poole-Wilson PA, Mann DL. The Seattle Heart Failure Model: prediction of survival in heart failure. Circulation 2006; 113: 1424-1433.

7. Stempfle HU, Alt A, Stief J, Siebert U. The Munich Score: A clinical index to predict survival in ambulatory patients with chronic heart failure in the era of new medical therapies. J Heart Lung Transplant 2008; 27: 222-228.

8. Poeltzl G, Ess M. Mussner Seeber C,Pachinger O, Frick M, Ulmer H. Liver dys function in chronic heart failure: prevalence, characteristic and prognostic significance. Eur J Clin Invest 2012; 42: 153-163.

9. Sherlock S, Dooley J. The hepatic artery and hepatic veins: The liver in circulatory failure. In: Sherlock S, Dooley J [ed.]. Diseases of the liver and biliary system. $11^{\text {th }}$ ed. Blackwell Science, Oxford 2002; 199-203.

10. Lau GT, Tan HC, Kritharides L. Type of liver dysfunction in heart failure and its relation to the severity of tricuspid regurgitation. Am J Cardiol 2002; 90: 1405-1409.

11. Myers JD, Hickam JB. An estimation of the hepatic blood flow and splanchnic oxygen consumption in heart failure. J Clin Invest 1948; 27: 620-627.

12. van Deursen VM, Damman K, Hillege HL, van Beek AP, van Veldhuisen DJ, Voors AA. Abnormal liver function in relation to hemodynamic profile in heart failure patients. J Cardiac Fail 2010; 16: 84-90.

13. Allen LA, Felker GM, Pocock S, Mc Murray JJV, Pfeffer MA, Swedberg K, Wang D, Yusuf S, Michelson EL, Granger CB for the CHARM Investigators. Liver function abnormalities and outcome in patients with chronic heart failure: data from the Candesartan in Heart Failure: Assessment of Reduction in Mortality and Morbidity (CHARM) program. Eur J Heart Fail 2009; 11: 170-177.

14. Szymik M, Szyguła-Jurkiewicz B, Partyka R, Owczarek A, Spinczyk B, Chudek J, Poloński L. Three-year survival of patients with chronic systolic heart failure due to hypertension: analysis of prognostic factors. Pol Arch Med Wewn 2012; 122: 543-550.

15. Szyguła-Jurkiewicz B, Wojnicz R, Lekston A, Duszańska A, Spinczyk B, Nowak J, Niklewski T, Helewski K, Poloński L. Effect of elevated bilirubin levels on the long-term outcome in patients with chronic heart failure due to hypertension. Pol Arch Med Wewn 2007; 117: 227-233.

16. Shinagawa H, Inomata T, Koitabashi T, Nakano H, Takeuchi I, Naruke T, Ohsaka T, Nishii M, Takehana H, Izumi T. Prognostic significance of increased serum bilirubin levels coincident with cardiac decompensation in chronic heart failure. Circ J 2008; 72: 364-369.
17. Malinchoc K, Kamath PS, Gordon FD, Peine CJ, Rank J, Borg TC. A model to predict poor survival in patients undergoing transjugular intrahepatic portosystemic shunts. Hepatology 2000; 31: 864-871.

18. Wiesner RH. Patient selection in an era of donor liver shortage: Current US policy. Nat Clin Pract Gastroenterol Hepatol 2005; 2: 24-30.

19. Kamath PS, Wiesner RH, Malinchoc M, Kremers W, Therneau TM, Kosberg CL, D’Amico G, Dickson ER, Kim WR. A model to predict survival in patients with end-stage liver disease. Hepatology 2001; 33: 464-470.

20. Teh SH, Nagorney DM, Stevens SR, Offord KP, Therneau TM, Plevak DJ, Talwalkar JA, Kim WR, Kamath PS. Risk factors for mortality after surgery in patients with cirrhosis. Gastroenterology 2007; 132: 1261-1269.

21. Suman A, Barnes DS, Zein NN, Levinthal GN, Connor JT, Carey WD. Predicting outcome after cardiac surgery in patients with cirrhosis: a comparison of Child-Pugh and MELD scores. Clin Gastroenterol Hepatol 2004; 2: 719-723.

22. Northup PG, Wanamaker RC, Lee VD, Adams RB, Berg CL. Model for EndStage Liver Disaese (MELD) predicts nontransplant surgical mortality in patients with cirrhosis. Ann Surg 2005; 242: 244-251.

23. Ailawadi G, Lapar DJ, Swenson BR, Siefert SA, Lau C, Kern JA, Peeler BB, Littlewood KE, Kron IL. Model for end-stage liver disease predicts mortality for tricuspid valve surgery. Ann Thorac Surg 2009; 87: 1460-1467.

24. Matthews JC, Pagani FD, Haft JW, Koelling TM, Naftel DC, Aaronson KD. Model for end-stage liver disease score predicts left ventricular assist device operative transfusion requirements, morbidity, and mortality. Circulation 2010; 121: 214-220.

25. Chokshi A, Cheeme FH, Schaefle KJ, Jiang J, Collado E, Shahzad K, Khawaja T, Farr M, Takayama H, Naka Y, Mancini DM, Schulze C. Hepatic dysfunction and survival after orthotopic heart transplantation: Application of the MELD scoring system for outcome prediction. J Heart Lung Transplant 2012; 31: 591-600.

26. Nwakanma LU, Williamss JA, Weiss ES, Russel SD, Baumgartner WA, Conte JV. Influence of pretransplant panel-reactive antibody on outcomes in 8160 heart transplant recipiens in recent era. Ann Thorac Surg 2007; 84: 15561562.

27. Heuman DM, Mihas AA, Habib A, Gilles HS, Stravitz RT, Sanyal AJ, Fisher RA MELD-XI: a rational approach to "sickest first" liver transplantation in cirrhotic patients requiring anticoagulant therapy. Liver Transpl 2007; 13: 30-37.

28. Assenza GE, Graham DA, Lanzberg MJ, Valente AM, Singh MN, Bashir A, Fernandes S, Mortele KJ, Ukomadu C, Volpe M, Wu F. MELD-IX score and cardiac mortality or transplantation in patients after Fontan surgery. Heart 2013; 99: 491-496.

29. Tsuda K, Koide M, Kunii Y, Watanabe K, Miyairi S, Ohashi Y, Harada T. Simplified model for end-stage liver disease score predicts mortality for tricuspid valve surgery. Int CardioVasc Thorac Surg 2013: 16: 630-635.

30. Kim MS, Kato TS, Farr M, Wu C, Givens RC, Collado E, Marcini DM, Schultze PC. Hepatic dysfunction in ambulatory patients with heart failure. J Am Coll Cardiol 2013; 61: 2253-2261. 